University of Wollongong

Research Online

Australian Institute for Innovative Materials -

Papers

Australian Institute for Innovative Materials

2014

One-pot synthesis of $\boldsymbol{\alpha}$-Fe203 nanoparticles-decorated reduced graphene oxide for efficient nonenzymatic $\mathrm{H} 2 \mathrm{O} 2$ biosensor

\author{
Ming-Yan Wang \\ University of Wollongong, mingyan@uow.edu.au \\ Tao Shen \\ Huaihai Institute of Technology \\ Meng Wang \\ University of Wollongong, mw088@uowmail.edu.au \\ Dong-En Zhang \\ Huaihai Institute of Technology \\ Zhi-wei Tong \\ Huaihai Institute of Technology
}

See next page for additional authors

Follow this and additional works at: https://ro.uow.edu.au/aiimpapers

Part of the Engineering Commons, and the Physical Sciences and Mathematics Commons

Research Online is the open access institutional repository for the University of Wollongong. For further information contact the UOW Library: research-pubs@uow.edu.au 


\title{
One-pot synthesis of $\boldsymbol{\alpha}$-Fe2O3 nanoparticles-decorated reduced graphene oxide for efficient nonenzymatic $\mathrm{H} 2 \mathrm{O} 2$ biosensor
}

\author{
Abstract \\ Hematite nanoparticles ( $\alpha$-Fe203) are successfully decorated on the reduced graphene oxide (rGO) \\ sheets through a simple, one-step, hydrothermal method without addition of other reducing agents. The \\ $\alpha-F e 203 / r G 0$ hybrid was characterized by scanning electron micrographs, $X$-ray diffraction, $X$-ray \\ photoelectron spectroscopy, and Raman spectroscopy. This $\alpha-F e 203 / \mathrm{rGO}$ hybrid has been successfully \\ applied in the catalytic performance toward the reduction of $\mathrm{H} 2 \mathrm{O} 2$. The nonenzymatic sensor \\ demonstrates a linear relationship over a wide concentration range of 5.0-4495.0 $\mu \mathrm{M}(\mathrm{R}=0.9998)$, a low \\ detection limit of $1.0 \mu \mathrm{M}$, and a high sensitivity of $126.9 \mu \mathrm{A} \mathrm{cm}-2 \mathrm{mM}-1$ to the detection of $\mathrm{H} 2 \mathrm{O} 2$.

\section{Keywords} \\ 202 , h, nonenzymatic, efficient, oxide, graphene, biosensor, reduced, one, decorated, nanoparticles, fe2o3, \\ synthesis, pot \\ Disciplines \\ Engineering | Physical Sciences and Mathematics

\section{Publication Details} \\ Wang, M., Shen, T., Wang, M., Zhang, D., Tong, Z. \& Chen, J. (2014). One-pot synthesis of $\alpha$-Fe2O3 \\ nanoparticles-decorated reduced graphene oxide for efficient nonenzymatic $\mathrm{H} 2 \mathrm{O} 2$ biosensor. Sensors \\ and Actuators, B: Chemical, 190 (January), 645-650.

\section{Authors} \\ Ming-Yan Wang, Tao Shen, Meng Wang, Dong-En Zhang, Zhi-wei Tong, and Jun Chen
}




\title{
One-pot synthesis of $a-\mathrm{Fe}_{2} \mathrm{O}_{3}$ nanoparticles-decorated reduced graphene oxide for efficient nonenzymatic $\mathrm{H}_{2} \mathrm{O}_{2}$ biosensor
}

\author{
Ming-Yan Wang ${ }^{\mathrm{a}, \mathrm{b}, *}$, Tao Shen ${ }^{\mathrm{a}}$, Meng Wang ${ }^{\mathrm{b}}$, Dong-En Zhang ${ }^{\mathrm{a}}$, Zhi-wei Tong ${ }^{\mathrm{a}}$, \\ Jun Chen ${ }^{\mathrm{b}, * *}$ \\ a Department of Chemical Engineering, Huaihai Institute of Technology, Lianyungang, 222005, China \\ ${ }^{\mathrm{b}}$ Intelligent Polymer Research Institute, ARC Centre of Excellence for Electromaterials Science, Australian Institute of Innova tive Materials, University of
} Wollongong, Northfields Avenue, Wollongong, NSW 2522, Australia

\section{a rticle i nfo}

\section{Article history:}

Received 5 July 2013

Received in revised form 21 August 2013

Accepted 26 August 2013

Available online 5 September 2013

\section{Keywords:}

$a-\mathrm{Fe}_{2} \mathrm{O}_{3}$ nanoparticles

Reduced graphene oxide

Nonenzymatic

Sensor

\begin{abstract}
a b s t r a c t
Hematite nanoparticles $\left(a-\mathrm{Fe}_{2} \mathrm{O}_{3}\right)$ are successfully decorated on the reduced graphene oxide (rGO) sheets through a simple, one-step, hydrothermal method without addition of other reducing agents. The $a$ $\mathrm{Fe}_{2} \mathrm{O}_{3}$ /rGO hybrid was characterized by scanning electron micrographs, $\mathrm{X}$-ray diffraction, $\mathrm{X}$-ray photoelectron spectroscopy, and Raman spectroscopy. This $a-\mathrm{Fe}_{2} \mathrm{O}_{3} / \mathrm{rGO}$ hybrid has been successfully applied in the catalytic performance toward the reduction of $\mathrm{H}_{2} \mathrm{O}_{2}$. The nonenzymatic sensor demonstrates a linear relationship over a wide concentration range of $5.0-4495.0 \mu \mathrm{M}(R=0.9998)$, a low detection limit of $1.0 \mu \mathrm{M}$, and a high sensitivity of $126.9 \mu \mathrm{A} \mathrm{cm}^{-2} \mathrm{mM}^{-1}$ to the detection of $\mathrm{H}_{2} \mathrm{O}_{2}$.
\end{abstract}

(C) 2013 Elsevier B.V. All rights reserved.

\section{Introduction}

The sensitive detection of $\mathrm{H}_{2} \mathrm{O}_{2}$ is important for its wide application in clinical, biopharmaceutical, and industrial procedures. $\mathrm{Au}$ [1], $\mathrm{Ag}$ [2], $\mathrm{Pt}$ [3], and other metals have been applied in non-enzyme electrochemical sensors because of their high electrocatalytic activities. Numerous biosensors and nanodevices have been fabricated based on $\mathrm{Au}, \mathrm{Ag}$, and Pt nanoparticles. However, a large number of low-cost sensors are required. Thus, exploring an efficient method of fabricating non-precious metal or metal-oxide sensors with high sensitivity and stability is of significant interest.

$\mathrm{Fe}_{2} \mathrm{O}_{3}$, an abundant, low-cost, and nontoxic metal oxide, is considered as one of the most promising candidate sensor materials $[4,5]$. Sun et al. [6] reported a novel biosensor fabricated by $a-$ $\mathrm{Fe}_{2} \mathrm{O}_{3}$ nanorod arrays for $\mathrm{H}_{2} \mathrm{O}_{2}$ detection. Xu et al. [7] reported the synthesis of nanoporous $a-\mathrm{Fe}_{2} \mathrm{O}_{3} / \mathrm{CoO}$ composites by a dealloying method for use in $\mathrm{H}_{2} \mathrm{O}_{2}$ detection. However, $a-\mathrm{Fe}_{2} \mathrm{O}_{3}$ suffers from a number of disadvantages, such as its relatively low conductivity and low electron transfer rate, both of which could significantly reduce its activity. An alternative strategy for preparing $a-\mathrm{Fe}_{2} \mathrm{O}_{3}$ is the use of conducting supports. Graphene has recently received

\footnotetext{
* Corresponding author. Tel.: +86 518 85895409; fax: +86 51885895401.

** Corresponding author. Tel.: +61 2 42213781; fax: +61 242213114.

E-mail addresses: mingyanlyg@hotmail.com (M.-Y.Wang), junc@uow.edu.au (J. Chen).
}

significant attention as an ideal support material for $a-\mathrm{Fe}_{2} \mathrm{O}_{3}$ because of its large surface area and high electrical conductivity. Wu et al. [8] reported that the photocatalytic water oxidation activ- ity of $a-\mathrm{Fe}_{2} \mathrm{O}_{3}$ is significantly increased by incorporating hematite on the reduced graphene oxide (rGO). Oh et al. [9] reported a novel graphene/nanotube $/ \mathrm{Fe}_{2} \mathrm{O}_{3} 3 \mathrm{D}$ hierarchical structure as an anode material in lithium-ion batteries. Graphene sheets allow effi- cient charge transfer and promote significantly specific capacities. Nevertheless, developing a facile method for preparing graphenesupported $a-\mathrm{Fe}_{2} \mathrm{O}_{3}$ by integrating the advantages of both graphene and nanoparticles remains a considerable challenge.

In this work, we report a facile one-pot hydrothermal method for synthesizing an $a-\mathrm{Fe}_{2} \mathrm{O}_{3}$-decorated $\mathrm{rGO}\left(a-\mathrm{Fe}_{2} \mathrm{O}_{3} / \mathrm{rGO}\right)$ hybrid without addition of other reducing agents. The fabrication process is illustrated in Scheme 1. First, $\mathrm{Fe}^{2+}$ ions were readily coordinated with negatively charged oxygen-containing functional groups on the GO sheets. Followed by the hydrothermal process, $\mathrm{Fe}^{2+}$ was oxidized into $\mathrm{Fe}^{3+}$ by the oxygen-containing functional groups on the GO surface [10]. Through hydrolysis of the $\mathrm{Fe}^{3+}$ ions, the resultant $a-\mathrm{Fe}_{2} \mathrm{O}_{3}$ nanoparticles were directly grown on the rGO sheets (in situ reduced from GO). This synthesis mechanism is similar to the previously reported formation of nanoparticlesdecorated rGOsheets $[11,12]$. Theas-prepared $a-\mathrm{Fe}_{2} \mathrm{O}_{3} / \mathrm{rGOhybrid}$ exhibits superparamagnetic behaviors, which allow easy handling of the materials using an external magnetic field (Scheme 1). The direct incorporation of $a-\mathrm{Fe}_{2} \mathrm{O}_{3}$ on rGO substrates provides good electrical contact between $a-\mathrm{Fe}_{2} \mathrm{O}_{3}$ and $\mathrm{rGO}$ and affords an 


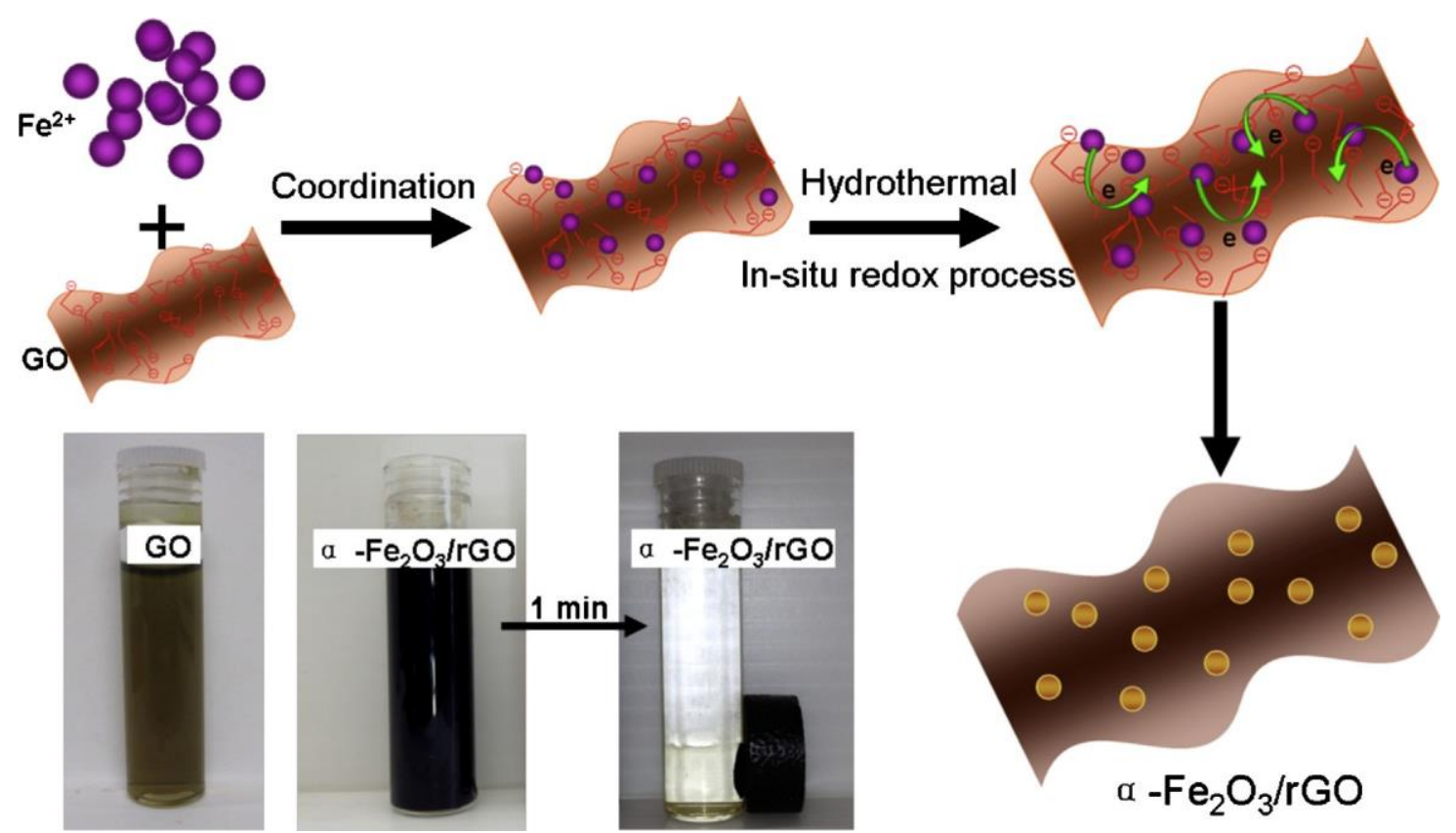

Scheme 1. Illustration of the synthetic route of $a-\mathrm{Fe}_{2} \mathrm{O}_{3} / \mathrm{rGO}$ hybrid and the photographic images of GO and $a-\mathrm{Fe}_{2} \mathrm{O}_{3} / \mathrm{rGO}$ (in the absence and presence of external magnetic field).

efficient pathway for charge transfer. Thus, the as-prepared $a$ $\mathrm{Fe}_{2} \mathrm{O}_{3} / \mathrm{rGO}$ hybrid exhibits significantly enhanced electrocatalytic performance in $\mathrm{H}_{2} \mathrm{O}_{2}$ reduction and may be successfully applied in $\mathrm{H}_{2} \mathrm{O}_{2}$ detection.

\section{Experimental}

\subsection{Synthesis of ، $-\mathrm{Fe}_{2} \mathrm{O}_{3} / \mathrm{rGO}$ nanocomposite}

Graphene oxide (GO) was synthesized by the modified Hummers method [13]. Briefly, $2 \mathrm{~g}$ of graphite powder and $1.25 \mathrm{gNaNO}_{3}$ were added to $60 \mathrm{~mL}$ of concentrated $\mathrm{H}_{2} \mathrm{SO}_{4}\left(0^{\circ} \mathrm{C}\right) .7 .5 \mathrm{~g}$ of $\mathrm{KMnO}_{4}$ was added gradually with stirring and cooling to maintain the mixture below $20{ }^{\circ} \mathrm{C}$. The mixture then stirred at $35{ }^{\circ} \mathrm{C}$ for $30 \mathrm{~min}$. $120 \mathrm{~mL}$ of distilled water was slowly added to the mixture and the temperature increased to $98^{\circ} \mathrm{C}$, then the mixture was maintained at this temperature for $15 \mathrm{~min}$. The reaction was terminated by adding $350 \mathrm{~mL}$ of distilled water followed by $10 \mathrm{~mL}$ of $30 \% \mathrm{H}_{2} \mathrm{O}_{2}$ solution. The solid product was separated by centrifugation, washed repeatedly with $5 \% \mathrm{HCl}$ solution until sulfate could not be detected with $\mathrm{BaCl}_{2}$, and then washed 3 times with ethanol and dried in vacuum at $60^{\circ} \mathrm{C}$ overnight. The resulting GO solution was ultrasound, then centrifuged to wipe off the unexploited graphite, and diluted in distilled water at a concentration of $2.5 \mathrm{mg} / \mathrm{mL}$.

A certain amount of $\mathrm{FeCl}_{2}$ was mixed with $2 \mathrm{~mL}$ of $\mathrm{GO}$ solution, and then the solution was dissolved into $30 \mathrm{~mL}$ distilled water. $100 \mu \mathrm{L}$ of $0.1 \mathrm{M}$ ammonia solution and $4 \mathrm{mmol}$ urea were added into the mixture and stirred for $2 \mathrm{~h}$ then transferred in a Teflon liner capacity, and then the liner was sealed in a stainless steel autoclave. The autoclave was maintained at $150^{\circ} \mathrm{C}$ for $2 \mathrm{~h}$ and then allowed to cool at room temperature using cool-water. The resulting precipitate was separated by filtration, and washed with distilled water and absolute ethanol for 5 times. Final dark-brown colored $a-\mathrm{Fe}_{2} \mathrm{O}_{3} / \mathrm{rGO}$ powders were achieved via vacuum-dry in a vacuum oven at $60^{\circ} \mathrm{C}$ for $5 \mathrm{~h}$. Various mass ratios of $\mathrm{Fe}^{2+}$ to $\mathrm{GO}$ were employed, the resulting samples were denoted as $a-\mathrm{Fe}_{2} \mathrm{O}_{3}-$ $0, a-\mathrm{Fe}_{2} \mathrm{O}_{3} / \mathrm{rGO}-1, a-\mathrm{Fe}_{2} \mathrm{O}_{3} / \mathrm{rGO}-2$ and $a-\mathrm{Fe}_{2} \mathrm{O}_{3} / \mathrm{rGO}-3$, according to the mass ratio of $\mathrm{Fe}^{2+}$ to GO changed from 1:0, to 1:1, 2:1 and
4:1. For comparison, rGO without adding ferrous salt (denoted as rGO- $x$ ) was also prepared under identical conditions.

\subsection{Physical characterization}

The crystalline properties and morphologies of the mate-rials were characterized by powder X-ray diffraction (XRD, D8-advanced, Bruker, $40 \mathrm{kV}, 20 \mathrm{~mA}, \mathrm{Cu} \mathrm{Ka}$ radiation), scanning electron microspcopy (SEM, JEOL, JSM6700F) equipped with an X-ray energy dispersive spectrometer (EDS) and transmission elec- tron microspcopy (TEM, JEOL-2010, voltage of $200 \mathrm{kV}$ ). The atomic composition was detected by X-ray photoelectron spectroscopy (XPS, Perkin Elmer, Al Ka radiation). Raman spectroscopy was performed using a Jobin-Yvon Lab Ram HR800 system.

\subsection{Electrochemical measurement}

All electrochemical experiments were performed on a CHI720 electrochemical workstation. Linear sweep voltammetry (LSV) and chronoamperometry (CA) testing were carried out using a threeelectrode cell, including a glassy carbon electrode (GCE) as the working electrode, an $\mathrm{Ag} / \mathrm{AgCl}$ electrode as the reference electrode, and a platinum wire electrode as the counter electrode. Electrochemical impedance spectroscopy (EIS) measurement was carried out at open circuit potential with an ac perturbation of $5 \mathrm{mV}$ in the frequency range from $0.01 \mathrm{~Hz}$ to $100 \mathrm{kHz}$ using a Solartron SI1260 Impedance Analyzer. For the working electrodes preparation, required amount of samples was ultrasonically dispersed in $0.081 \%$ Nafion solution toobtain $2 \mathrm{mg} / \mathrm{mL}$ uniformink. Then $10 \mu \mathrm{L}$ of the ink was dropped on the GCE and dried in the air before the electrochemical tests. The catalyst loading on the electrode was maintained as $80 \mu \mathrm{gcm}^{-2}$ for all the electrochemical testing.

\section{Results and discussion}

\subsection{Morphology analysis}

The morphology of the resulting $a-\mathrm{Fe}_{2} \mathrm{O}_{3} / \mathrm{rGO}$ was investigated by SEM and TEM (Fig. 1). The SEM image reveals that the hybrid has 

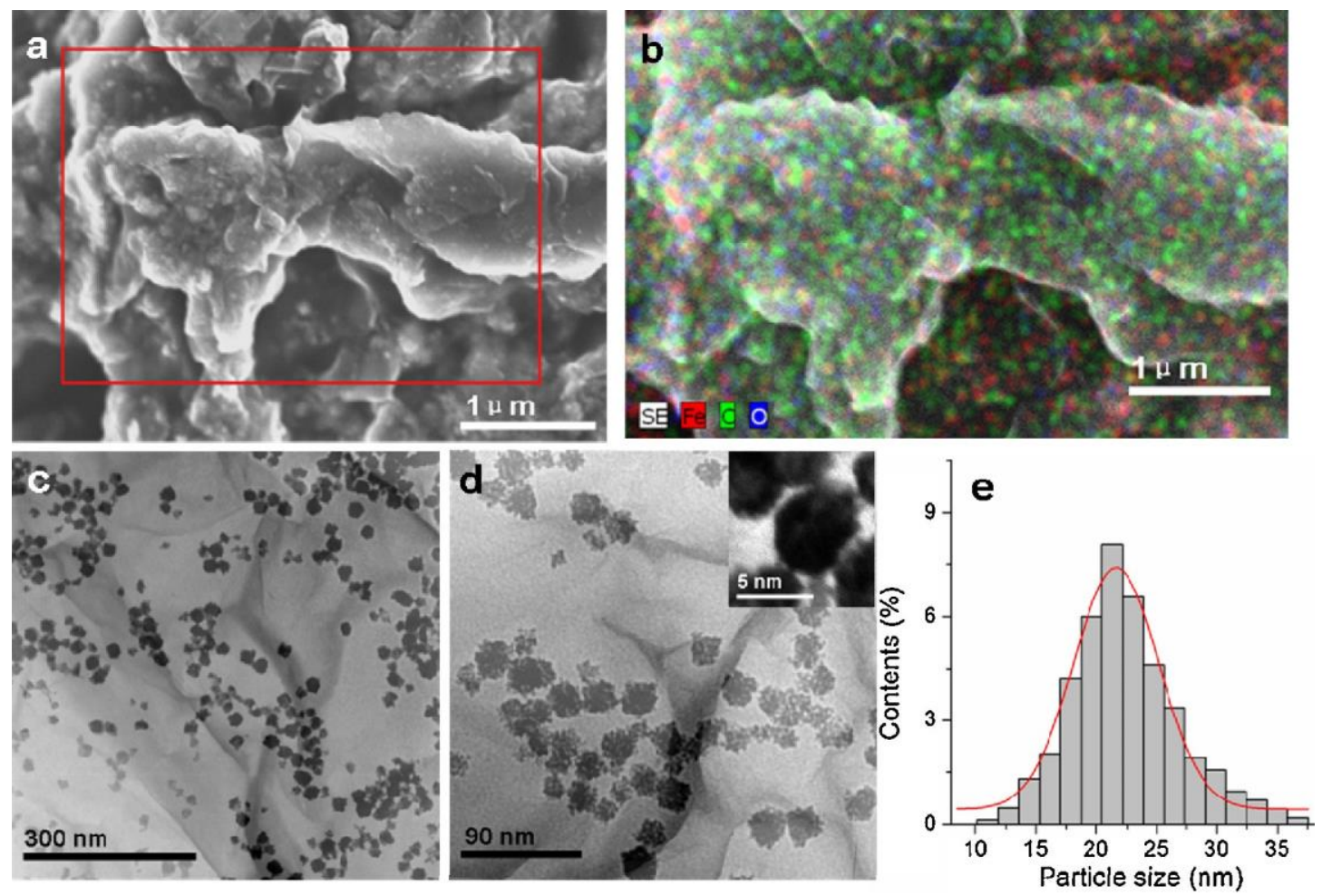

Fig. 1. SEM image (a), EDS elemental mapping analysis (b) and TEM images (c and d) of $a-\mathrm{Fe}_{2} \mathrm{O}_{3} / \mathrm{rGO}$ hybrid (inset of d: high-resolution TEM image of $a$-Fe $\mathrm{e}_{2} / \mathrm{rGO}$ ). (e) Particle size distribution histograms of $a-\mathrm{Fe}_{2} \mathrm{O}_{3} / \mathrm{rGO}$ hybrid. The hybrid used in (a) -(e) is $a-\mathrm{Fe}_{2} \mathrm{O}_{3} / \mathrm{rGO}-3$ with the mass ratio of $\mathrm{Fe}^{2+}$ to GO $4: 1$.

a coarse surface because of the incorporation of small crystalline $a-\mathrm{Fe}_{2} \mathrm{O}_{3}$ nanoparticles on the rGO sheets (Fig. 1a). EDS elemental mappinganalysisindicated the presenceof $\mathrm{Fe}, \mathrm{C}$, and Ocomponents in the hybrid (Fig. 1b). The TEM image (Fig. 1c) clearly shows that the rGO sheets possess 2D layered structure that mainly consists of a monolayer or a few-layer carbon nanostructure. A large number of iron oxide nanoparticles with spherical morphologies are homogeneously anchored to the rGO sheets surface. Close observation (Fig. 1d) reveals that these spherical $a-\mathrm{Fe}_{2} \mathrm{O}_{3}$ aggregates, which consist of much smaller nanoparticles, are approximately 21.65 Q.46 nm in diameter as shown in Fig. 1e. High-resolution TEM observations (inset in Fig. 1d) further indicate that the mean size of the nanocrystal subunit is approximately $5 \mathrm{~nm}$.

\subsection{Physical characterization of ${ }_{2}-\mathrm{Fe}_{2} \mathrm{O}_{3} / \mathrm{rGO}$ hybrids}

XRD has been used to investigate the phase structure of the resulting hybrids as shown in Fig. 2. The as-prepared GO displays a characteristic $\left(\begin{array}{lll}0 & 0 & 2\end{array}\right)$ peak at $9.4^{\circ}$ [14]. After the hydrothermal process, the XRD patterns of all the ferric hybrids with different mass ratios of $\mathrm{Fe}^{2+}$ to $\mathrm{GO}$ exhibit the crystalline $a-\mathrm{Fe}_{2} \mathrm{O}_{3}$ diffraction peaks, which are in good agreement with the standard $a-\mathrm{Fe}_{2} \mathrm{O}_{3}$ (JCPDS Card: 33-0664), indicating that in the hybrids $a-\mathrm{Fe}_{2} \mathrm{O}_{3}$ has been successfully synthesized $[15,16]$. Interestingly, with a higher concentration of $\mathrm{Fe}^{2+}$ ions in the mixture $\left(a-\mathrm{Fe}_{2} \mathrm{O}_{3} / \mathrm{rGO}-3\right.$, the mass ratio of $\mathrm{Fe}^{2+}$ to GO 4:1), a broad (0 0 2) peak was detected at approximately $24.2^{\circ}$, which can be indexed as disordered stacked graphitic sheets, indicating GO has been reduced to $\mathrm{rGO}$, similar to the reported previously [17]. However, if the mass ratio of $\mathrm{Fe}^{2+}$ ions to GO was lower than 2:1, the resulting sample was not so highly reduced in comparison with that of $a-\mathrm{Fe}_{2} \mathrm{O}_{3} / \mathrm{rGO}-3$, which can be validated by the content of oxygen-containing carbon in deconvoluted C 1s XPS spectra of the ferric hybrids (Fig. S1). This observation suggests that in this hydrothermal approach, $\mathrm{Fe}^{2+}$ ions were introduced as a reducing agent to reduce graphene oxide sheets, so the reduction level of GO sheets in the hybrids largely depended on the amount of the reducing agent $\mathrm{Fe}^{2+}$. This is in accordance with previously reported results of reduced graphite oxide [10]. Need to point out that, during the hybrids formation, if no ferrous chloride existed in the mixture, GO can not be completely reduced and its XRD pattern displays a weak peak at $8.7^{\circ}$ corresponding to GO structure (Fig. S2). Furthermore, the XPS spectrum of rGO- $x$ (Fig. S3) show only some of the oxygen-containing functional groups in GO have been removed by hydrothermal process without adding ferrous chloride, this result is consistent with the XRD data.

To investigate the chemical states of elements in the hybrids, the wide-scan XPS was carried out and the results are shown in Fig. 3. The peaks in the wide-scan XPS spectrum of $a-\mathrm{Fe}_{2} \mathrm{O}_{3} / \mathrm{rGO}$ (Fig. 3a) correspond to the characteristic peaks of $\mathrm{C} 1 \mathrm{~s}, \mathrm{O} 1 \mathrm{~s}, \mathrm{Fe} 2 \mathrm{p}$ and $\mathrm{Fe}$

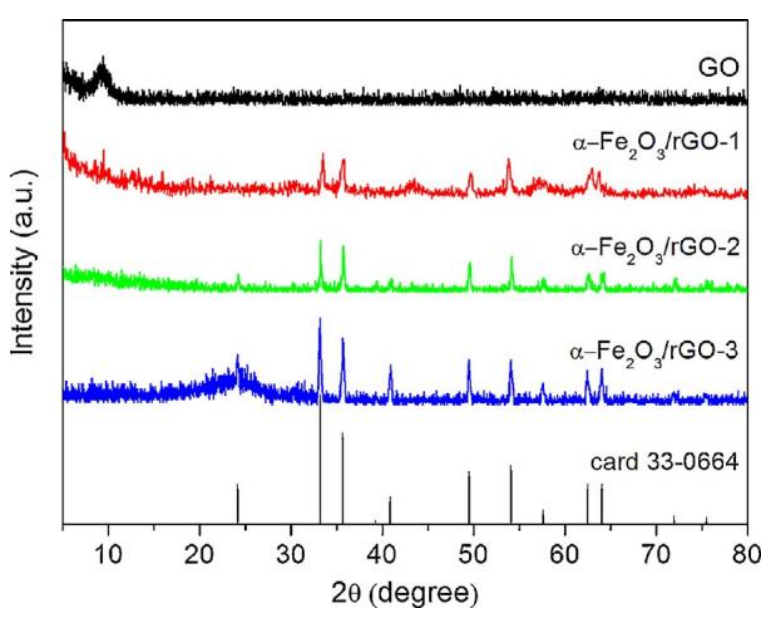

Fig. 2. XRD patterns of $\mathrm{GO}, a-\mathrm{Fe}_{2} \mathrm{O}_{3} / \mathrm{rGO}-1, a-\mathrm{Fe}_{2} \mathrm{O}_{3} / \mathrm{rGO}-2$ and $a-\mathrm{Fe}_{2} \mathrm{O}_{3} / \mathrm{rGO}-3$. 

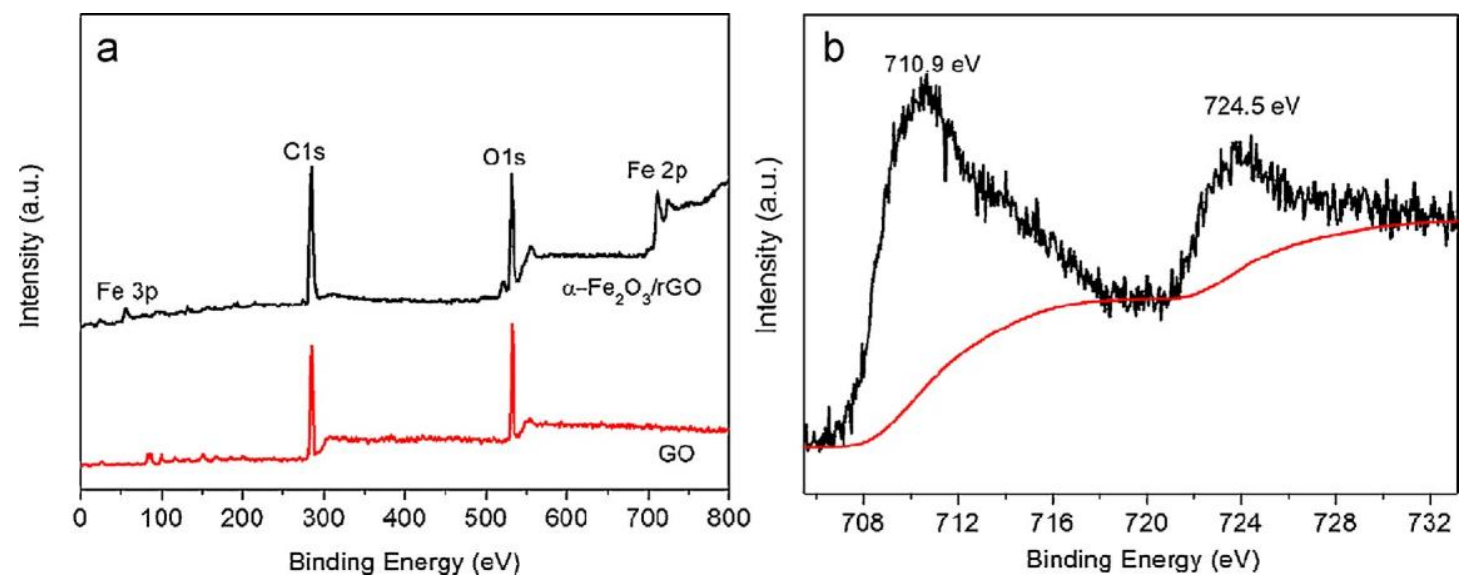

Fig. 3. (a) XPS survey spectra of $\mathrm{GO}$ and $a-\mathrm{Fe}_{2} \mathrm{O}_{3} / \mathrm{rGO}$. (b) $\mathrm{Fe} 2 \mathrm{p}$ XPS of $a-\mathrm{Fe}_{2} \mathrm{O}_{3} / \mathrm{rGO}$. The hybrid used in (a) and (b) is $a$-Fe $2 \mathrm{O}_{3} / \mathrm{rGO} 3$ with the mass ratio of $\mathrm{Fe}^{2+}$ to GO $4: 1$.

$3 p$, indicating the existence of carbon, oxygen and Fe elements in the sample, this result is consistent with EDS elemental mapping analysis. The XPS spectrum for Fe $2 p$ shown in Fig. $3 b$ exhibits two major peaks with binding energies at 710.9 and $724.5 \mathrm{eV}$ corresponding to $\mathrm{Fe} 2 \mathrm{p}_{3 / 2}$ and $\mathrm{Fe} 2 \mathrm{p}_{1 / 2}$, respectively, which is characteristic of $\mathrm{Fe}^{3+}$ in $\mathrm{Fe}_{2} \mathrm{O}_{3}$ [6].

To further investigate the interaction between components of $a-\mathrm{Fe}_{2} \mathrm{O}_{3} /$ rGO hybrids, Raman spectroscopy has been used and the results are shown in Fig. 4. The five characteristic peaks in the range of 200-1000 $\mathrm{cm}^{-1}$ observed in the Raman spectra of the $a$ $\mathrm{Fe}_{2} \mathrm{O}_{3} / \mathrm{rGO}$ hybrids can be assigned to two classes of Raman active vibration modes, $\mathrm{A}_{1 \mathrm{~g}}$ modes $\left(225,498 \mathrm{~cm}^{-1}\right)$ and $\mathrm{E}_{\mathrm{g}}$ modes $(293,412$, $613 \mathrm{~cm}^{-1}$ ) of $a-\mathrm{Fe}_{2} \mathrm{O}_{3}$ [18]. It is noted that $\mathrm{GO}$ exhibits a $\mathrm{G}$ band at $1606 \mathrm{~cm}^{-1}$, while the corresponding $\mathrm{G}$ bands of $a-\mathrm{Fe}_{2} \mathrm{O}_{3} / \mathrm{rGO}$ hybrids are 1589,1584 and $1587 \mathrm{~cm}^{-1}$, respectively. The red shifts of $\mathrm{G}$ band of ferric hybrids can be attributed to the high ability for recovery of the hexagonal network of carbon in rGO [19], which is consistent with the decrease of the D/G ratio. In other words, the red shifts and increases of $G$ bands suggest the reduction of the GO in the ferric hybrids.

Thus, for the above analyses, it was reasonable to conclude that GOsheetcan beeffectivereduced torGOthrough thishydrothermal process assisted with a sufficient amount of $\mathrm{Fe}^{2+}$ ion, and in situ simultaneous the resultant $a-\mathrm{Fe}_{2} \mathrm{O}_{3}$ nanoparticles anchored on the rGO sheets to form $a-\mathrm{Fe}_{2} \mathrm{O}_{3} / \mathrm{rGO}$ hybrids. Yu et al. [10] and Li et al. [20] also reported the synergistic effects of the reduction of GO by metal ions to access graphene-based hybrids.

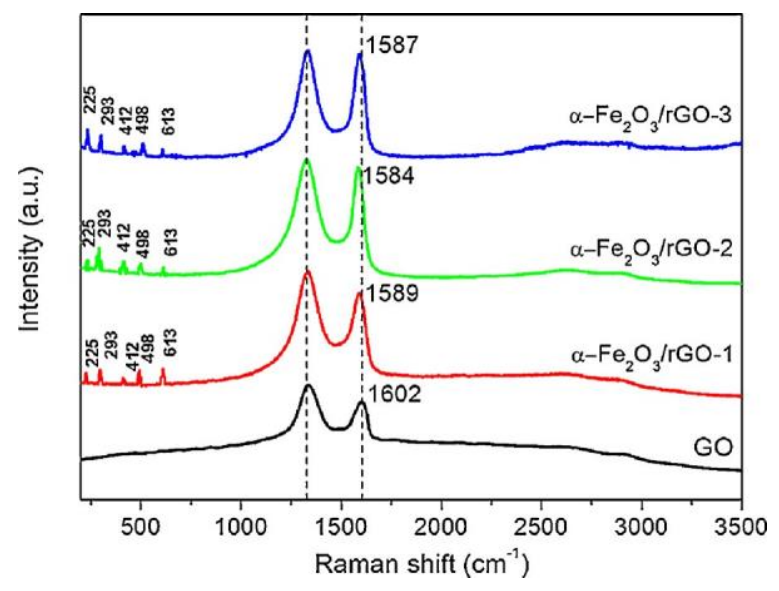

Fig. 4. Raman spectra of $\mathrm{GO}, a-\mathrm{Fe}_{2} \mathrm{O}_{3} / \mathrm{rGO}-1, a-\mathrm{Fe}_{2} \mathrm{O}_{3} / \mathrm{rGO}-2$ and $a-\mathrm{Fe}_{2} \mathrm{O}_{3} / \mathrm{rGO}-3$.

\subsection{Electrochemical measurement}

The electrochemical performance of the as-prepared materials was evaluated by linear sweep voltammetry (LSV) and electrochemical impedance spectroscopy (EIS). Fig. 5 shows that as the mass ratio of $\mathrm{Fe}^{2+}$ to GO increases, $a-\mathrm{Fe}_{2} \mathrm{O}_{3} / \mathrm{rGO}-3$ exhibits a notable catalytic reduction current peak at $-0.22 \mathrm{~V}$ vs. $\mathrm{Ag} / \mathrm{AgCl}$ and no electrochemical response in the absence of $\mathrm{H}_{2} \mathrm{O}_{2}$, indicating catalytic $\mathrm{H}_{2} \mathrm{O}_{2}$ reduction. By contrast, independent $a-\mathrm{Fe}_{2} \mathrm{O}_{3}-0$ and rGO exhibited extremely low activities for $\mathrm{H}_{2} \mathrm{O}_{2}$ reduction under identical conditions. These observations show that $a-\mathrm{Fe}_{2} \mathrm{O}_{3} / \mathrm{rGO}-3$ has notable catalytic activity for $\mathrm{H}_{2} \mathrm{O}_{2}$ reduction. An electrocat- alytic process involves adsorption phenomena as well as several reactions at the electrode/electrolyte interface. Thus, the surface accessibility of the nanocomposites is crucial in maintaining their high electroactivities. Here, the $a-\mathrm{Fe}_{2} \mathrm{O}_{3}$ loading on the graphitic sheets efficiently prevented the graphene sheet aggregation and consequently increase the electrochemical active surface area. In addition, the good electrical contact and the efficient path- way for charge transfer between $a-\mathrm{Fe}_{2} \mathrm{O}_{3}$ and rGO make the nanostructured $a$ $\mathrm{Fe}_{2} \mathrm{O}_{3} /$ rGO composite promising for the use as electrochemical sensor.

EIS was employed to probe the electron transfer kinetics of the ferric hybrids. As shown in Fig. 6, a semicircular and a linear are observed for these electrodes, the semicircular corresponding to the charge transfer resistance, and the linear portion corresponding to the diffusion limited process [21]. Obviously, the diameter of

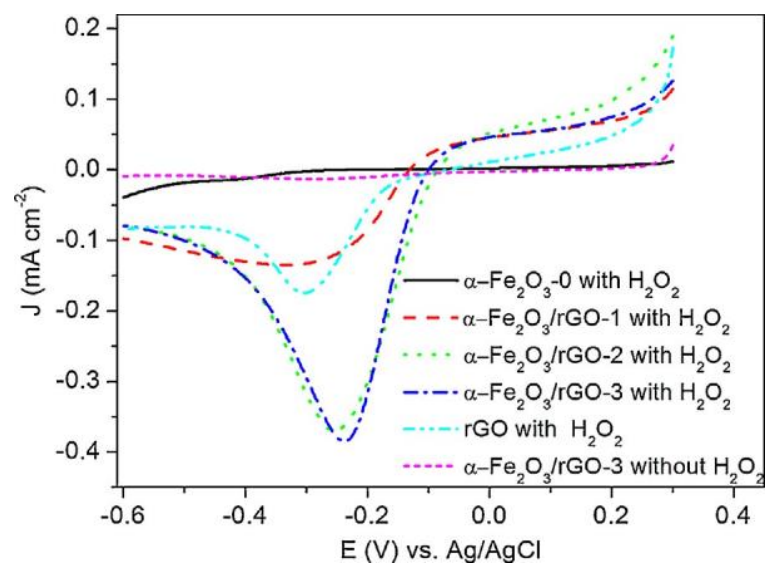

Fig. 5. LSV curves of $a-\mathrm{Fe}_{2} \mathrm{O}_{3}-0, a-\mathrm{Fe}_{2} \mathrm{O}_{3} / \mathrm{rGO}-1, a-\mathrm{Fe}_{2} \mathrm{O}_{3} / \mathrm{rGO}-2, a-\mathrm{Fe}_{2} \mathrm{O}_{3} / \mathrm{rGO}-3$ and rGO modified GCEs in $0.1 \mathrm{M} \mathrm{KOH} \mathrm{N} \mathrm{N}_{2}$ saturated solution in the presence or absence of $3.0 \mathrm{mMH}_{2} \mathrm{O}_{2}$ 


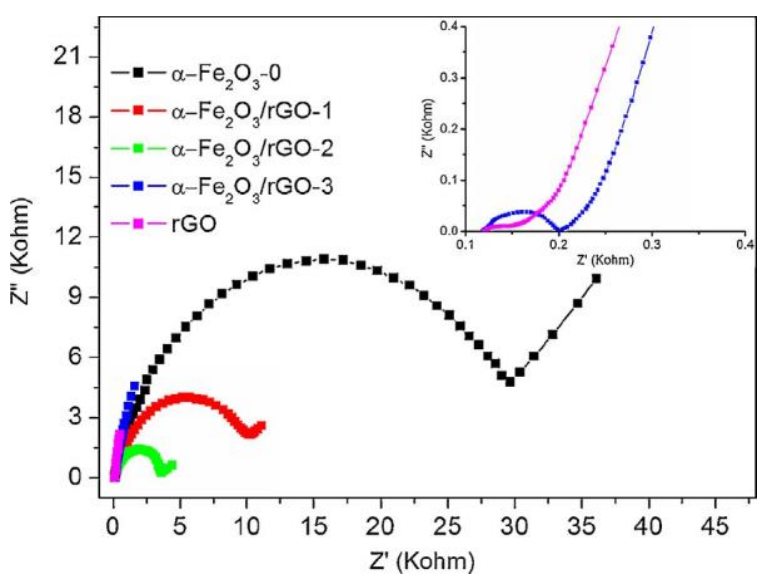

Fig. 6. Nyquist plots of $a-\mathrm{Fe}_{2} \mathrm{O}_{3}-0, a-\mathrm{Fe}_{2} \mathrm{O}_{3} / \mathrm{rGO}-1, a-\mathrm{Fe}_{2} \mathrm{O}_{3} / \mathrm{rGO}-2, a-\mathrm{Fe}_{2} \mathrm{O}_{3} / \mathrm{rGO}-3$, and rGO at the open potential.

the semicircular for $a-\mathrm{Fe}_{2} \mathrm{O}_{3} / \mathrm{rGO}-3$ is the smallest among those hybrids and almost similar with that of rGO. This indicates that with the mass ratio of $\mathrm{Fe}^{2+}$ to $\mathrm{GO}$ increasing, $\mathrm{GO}$ was effectively reduced to $\mathrm{rGO}$, the electron transfer performance of the ferric hybrid was significantly enhanced, which could make the catalytic reduction of $\mathrm{H}_{2} \mathrm{O}_{2}$ much easier and more efficiently than $a-\mathrm{Fe}_{2} \mathrm{O}_{3}$ without rGO supports.

Fig. 7a presents a typical steady response with successive addition of $\mathrm{H}_{2} \mathrm{O}_{2}$ at $\_.22 \mathrm{~V}$. A quick amperometric response is observed within $2 \mathrm{~s}$ at $95 \%$ steady state current (inset of Fig. 7a). This kind of $\mathrm{H}_{2} \mathrm{O}_{2}$ sensor exhibits a wide linear relationship in the range from 5.0 to $4495.0 \mu \mathrm{M}(R=0.9998)$ with a high sensitivity of $126.9 \mu \mathrm{Acm}^{-2} \mathrm{mM}^{-1}$ (Fig. $7 \mathrm{~b}$ ). In addition, the detection limit is
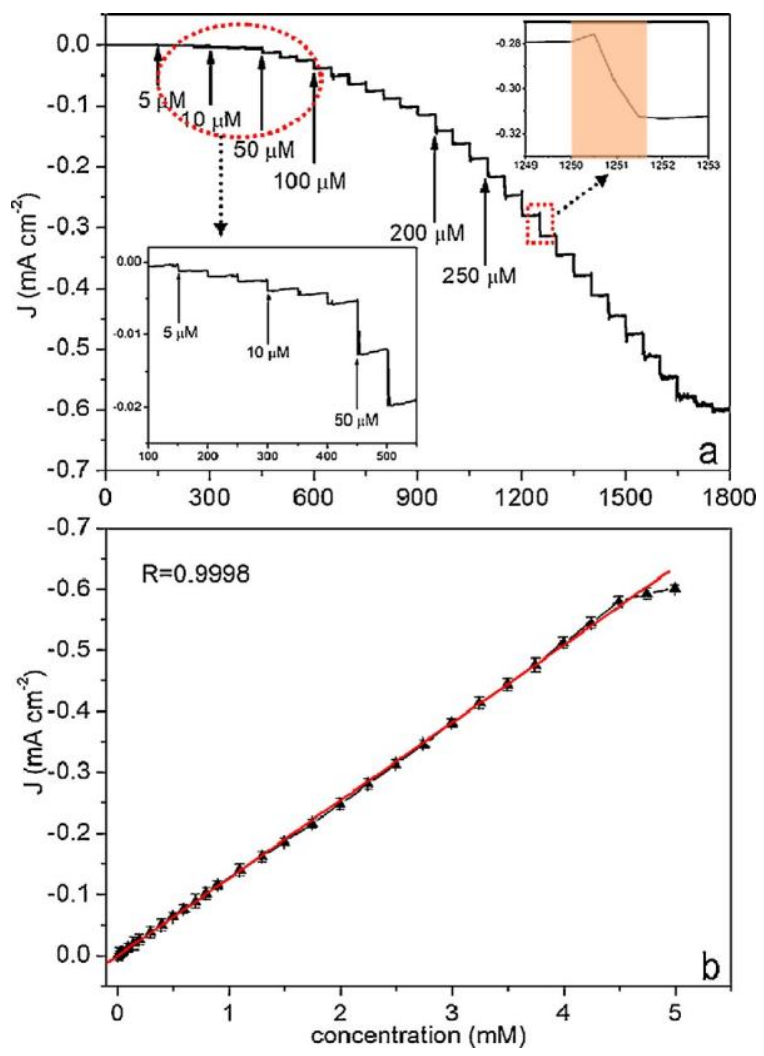

Fig. 7. (a) Steady-state response of the $a-\mathrm{Fe}_{2} \mathrm{O}_{3} / \mathrm{rGO}$ to successive injection of $\mathrm{H}_{2} \mathrm{O}_{2}$ into $0.1 \mathrm{M} \mathrm{KOH} \mathrm{N}$ saturated solution; (b) the calibration curve of the reduction currents versus the concentrations of $\mathrm{H}_{2} \mathrm{O}_{2}$. The hybrid used in (a) and (b) is a$\mathrm{Fe}_{2} \mathrm{O}_{3} / \mathrm{rGO}-3$ with the mass ratio of $\mathrm{Fe}^{2+}$ to GO 4:1.
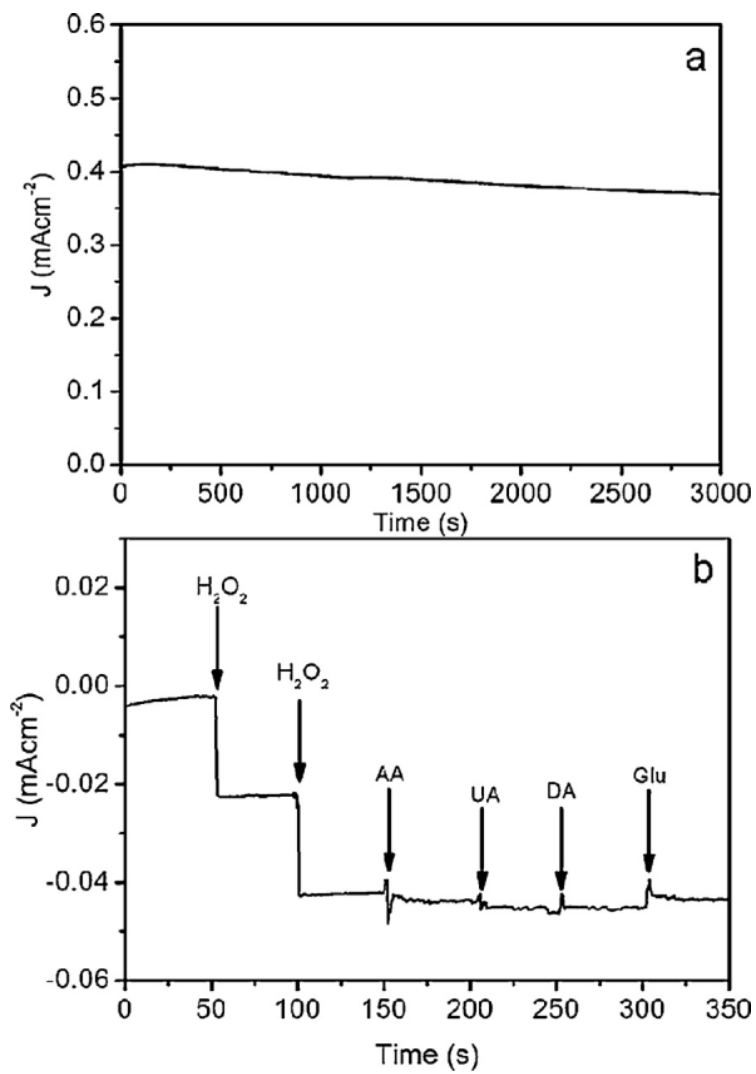

Fig. 8. (a) The long-term stability of $a-\mathrm{Fe}_{2} \mathrm{O}_{3} / \mathrm{rGO}$ sensor with $3.0 \mathrm{mM} \mathrm{H}_{2} \mathrm{O}_{2}$ in $0.1 \mathrm{M}$ $\mathrm{KOH}$ solution at the potential of $-0.22 \mathrm{~V}$. (b) Current-time curve for the $a-\mathrm{Fe}_{2} \mathrm{O}_{3} / \mathrm{rGO}$ exposed to $\mathrm{H}_{2} \mathrm{O}_{2}(0.1 \mathrm{mM})$, UA, AA, DA $(0.05 \mathrm{mM})$, and $\mathrm{Glu}(0.5 \mathrm{mM})$. The hybrid used is $a-\mathrm{Fe}_{2} \mathrm{O}_{3} / \mathrm{rGO}-3$ with the mass ratio of $\mathrm{Fe}^{2+}$ to GO 4:1.

calculated to be about $1.0 \mu \mathrm{M}$ at the signal-to-noise ratio of 3 . The relative standard deviation (RSD) of the current response to $3.0 \mathrm{mM}$ $\mathrm{H}_{2} \mathrm{O}_{2}$ is $3.2 \%$ for 6 successive measurements.

Comparative results of the performance of this fabricated biosensor as well as other $\mathrm{Fe}_{2} \mathrm{O}_{3}$-based biosensor in $\mathrm{H}_{2} \mathrm{O}_{2}$ detection are listed in Table 1 . The detection limit, linear calibration range, and sensitivity of the proposed sensor were either comparable with or higher than those provided by other $\mathrm{Fe}_{2} \mathrm{O}_{3}$ or $\mathrm{Fe}_{2} \mathrm{O}_{3}$-hybrid- modified electrodes.

The catalytic stability of the hybrid is evaluated by studying its steady state response with time. The chronoamperometry experiments under $-0.22 \mathrm{~V}$ are shown in Fig. $8 \mathrm{a}$, the addition of $3.0 \mathrm{mM}$ $\mathrm{H}_{2} \mathrm{O}_{2}$ in stirring $0.1 \mathrm{MKOH}$ solution exhibits a stable amperometric response after running for $3000 \mathrm{~s}$ with only $7 \%$ activity decay. The sensingstability of the $a-\mathrm{Fe}_{2} \mathrm{O}_{3} / \mathrm{rGOhybrid} \mathrm{was} \mathrm{further} \mathrm{explored} \mathrm{by}$ continuous detecting $\mathrm{H}_{2} \mathrm{O}_{2}$ every day for two weeks. The recorded amperometric response of the hybrid towards $3.0 \mathrm{mM} \mathrm{H}_{2} \mathrm{O}_{2}$ has almost no change over two weeks. These results demonstrated that this $a-\mathrm{Fe}_{2} \mathrm{O}_{3} / \mathrm{rGO}$ hybrid biosensor is highly stable and efficient at $\mathrm{H}_{2} \mathrm{O}_{2}$ detection. The electrode-to-electrode reproducibility was checked by using the amperometric response of $3.0 \mathrm{mM} \mathrm{H}_{2} \mathrm{O}_{2}$. A total of seven freshly prepared modified electrodes were tested and the RSD was found to be $2.6 \%$. It is clear that the $a-\mathrm{Fe}_{2} \mathrm{O}_{3} / \mathrm{rGO}$ hybrid show good long-term stability and excellent reproducibility for $\mathrm{H}_{2} \mathrm{O}_{2}$ detection.

Several typical interferences including ascorbic acid (AA), uric acid(UA), dopamine (DA), glucose (Glu) arechosen to test the selectivity in which no apparent interferences are observed (Fig. 8b). Based on the above experiment results, this $a-\mathrm{Fe}_{2} \mathrm{O}_{3} / \mathrm{rGO}$ hybrid has great potential to achieve high sensitivity and stability biosensors. 
Table 1

Comparison of analytical characteristics of $\mathrm{Fe}_{2} \mathrm{O}_{3}$-based biosensor for the $\mathrm{H}_{2} \mathrm{O}_{2}$ detection

\begin{tabular}{|c|c|c|c|c|}
\hline Configuration of biosensor & Sensitivity $\left(\mu \mathrm{A} \mathrm{cm}^{-2} \mathrm{mM}^{-1}\right)$ & Detection limit $(\mu \mathrm{M})$ & Linear range $(\mu \mathrm{M})$ & Reference \\
\hline$a-\mathrm{Fe}_{2} \mathrm{O}_{3}$ nanorod arrays & 77.3 & 0.2 & $0.5-3000$ & [6] \\
\hline$a-\mathrm{Fe}_{2} \mathrm{O}_{3} / \mathrm{CoO}$ & - & 0.1 & $50-4850$ & [7] \\
\hline $\mathrm{PB}-\mathrm{Fe}_{2} \mathrm{O}_{3}$ & 7.3 & 7.0 & $20-300$ & {$[22]$} \\
\hline$-y-\mathrm{Fe}_{2} \mathrm{O}_{3}-\mathrm{LaB}_{6}$ & - & 0.06 & $0.2-600$ & [23] \\
\hline Amorphous $\mathrm{Fe}_{2} \mathrm{O}_{3}$ & - & 20 & $20-8500$ & [24] \\
\hline$-y-\mathrm{Fe}_{2} \mathrm{O}_{3}$ nanoparticles & 58 & 2.78 & $10-1500$ & [25] \\
\hline$a-\mathrm{Fe}_{2} \mathrm{O}_{3} / \mathrm{rGO}$ & 126.9 & 1.0 & $5.0-4495.0$ & This work \\
\hline
\end{tabular}

\section{Conclusion}

$a-\mathrm{Fe}_{2} \mathrm{O}_{3}$ nanoparticles with an average size of $21 \mathrm{~nm}$ were successfully decorated on the rGO sheets through a simple, one-step, hydrothermal method. In this hydrothermal process, $\mathrm{Fe}^{2+}$ ions were introduced as a reducing agent, and GO sheets were effectively reduced to rGO in the presence of a sufficient amount of $\mathrm{Fe}^{2+}$ ions. The resultant $a-\mathrm{Fe}_{2} \mathrm{O}_{3}$ nanoparticles simultaneously anchored onto the rGO sheets in situ to form an $a-\mathrm{Fe}_{2} \mathrm{O}_{3} / \mathrm{rGO}$ hybrid. The $a$ $\mathrm{Fe}_{2} \mathrm{O}_{3} / \mathrm{rGO}$ hybrid exhibited excellent electrocatalytic activity for $\mathrm{H}_{2} \mathrm{O}_{2}$ electrochemical reduction and is thus a promising sensor material.

\section{Acknowledgments}

This work was supported by National Natural Science Foundation of China (Grant Nos. 51202079 and 21201070). A project funded by the Priority Academic Program development of Jiangsu Higher Education Institutions. The authors are grateful to National College Student's Innovation Project and the young teachers of Jiangsu Province universities' "blue and green blue project". The authors also acknowledge the Australian National Fabrication Facility (ANFF) for provision of services and equipment access.

\section{Appendix A. Supplementary data}

\section{References}

[1] G.K. Parshetti, F.H. Lin, R.A. Doong, Sensitive amperometric immunosensor fo $a$-fetoprotein detection based on multifunctional dumbbell-like $\mathrm{Au}-\mathrm{Fe}_{3} \mathrm{O}_{4}$ het erostructures, Sensors and Actuators B 186 (2012) 34-43.

[2] K. Liao, P. Mao, Y. Li, F. Song, G. Wang, M. Han, A promising method for fabricating $\mathrm{Ag}$ nanoparticle modified nonenzyme hydrogen peroxide sensors, Sensors and Actuators B 181 (2013) 125-129.

[3] C. Xu, J. Wang, J. Zhou, Nanoporous PtNi alloy as an electrochemical sensor for ethanol and $\mathrm{H}_{2} \mathrm{O}_{2}$, Sensors and Actuators B 182 (2013) 408-415.

[4] Y. Wang, J.L. Cao, M.G. Yu, G. Sun, X.D. Wang, H. Bala, Z.Y. Zhang, Porous a-Fe2 hollow microspheres: hydrothermal synthesis and their application in ethanol sensors, Materials Letters 100 (2013) 102-103.

[5] P.V. Adhyapak, U.P. Mulik, D.P. Amalnerkar, I.S. Mulla, Low temperature synthesis of needle-like $a-\mathrm{FeOOH}$ and their conversion into $a-\mathrm{Fe}_{2} \mathrm{O}_{3}$ nanorods for humidity sensing application, Journal of American Ceramic Society 96 (2013) $731-735$

[6] X. Liu, J. Liu, Z. Chang, L. Luo, X. Lei, X. Sun, $a-\mathrm{Fe}_{2} \mathrm{O}_{3}$ nanorod arrays for bioanalytical applications: nitrite and hydrogen peroxide detection, RSC Advances 3 (2013) 8489-8494

[7] J. Wang, H. Gao, F. Sun, Q. Hao, C. Xu, Highly sensitive detection of hydrogen peroxide based on nanoporous $\mathrm{Fe}_{2} \mathrm{O}_{3} / \mathrm{CoO}$ composites, Biosensors and Bioelectronics 42 (2013) 550-555.

[8] F. Meng, J. Li, S.K. Cushing, J. Bright, M. Zhi, J.D. Rowley, Z. Hong, A. Maniwannan, A.D. Bristow, N. Wu, Photocatalytic water oxidation by hematite/reduced graphene oxide composites, ACS Catalysis 3 (2013) 746-751.

[9] S.H. Lee, V. Sridhar, J.H. Jung, K. Karthikeyan, Y.S. Lee, R. Mukherjee, N. Koratkar, I.K. Oh, Graphene-nanotube-iron hierarchical nanostructure as lithium ion battery anode, ACS Nano 7 (2013) 4242-4251.

[10] H.P. Cong, X.C. Ren, P. Wang, S.H. Yu, Macroscopic multifunctional graphenebased hydrogels and aerogels by a metal ion induced self-assembly process, ACS Nano 6 (2012) 2693-2703.

[11] S. Chen, J. Zhu, X. Wu, Q. Han, X. Wang, Graphene oxide- $\mathrm{MnO}_{2}$ nanocomposites for supercapacitors, ACS Nano 4 (2010) 2822-2830.
[12] H. Wang, H.S. Casalongue, Y. Liang, H. Dai, $\mathrm{Ni}(\mathrm{OH})_{2}$ nanoplates grown on graphene as advanced electrochemical pseudocapacitor materials, Journal of American Chemical Society 132 (2010) 7472-7477.

[13] Hummers F W.S., R.E. Offeman, Preparation of graphitic oxide, Journal of American Chemical Society 80 (1958) 1339

[14] D. Antiohos, K. Pingmuang, M.S. Romano, S. Romano, S. Beirne, T. Romeo, P. Aitchison, A. Minett, G. Wallace, S. Phanichphant, J. Chen, Manganositemicrowave exfoliated graphene oxide composites for asymmet- ric supercapacitor device applications, Electrochimica Acta 101 (2013) 99-108.

[15] E. Darezereshki, One-step synthesis of hematite $\left(a-\mathrm{Fe}_{2} \mathrm{O}_{3}\right)$ nano-particles by direct thermal-decomposition of maghemite, Materials Letters 65 (2011) 642645.

[16] Z. An, J. Zhang, S. Pan, F. Yu, Facile template-free and characterization of elliptic $a-\mathrm{Fe}_{2} \mathrm{O}_{3}$ superstructures, Journal of Physical Chemistry C 113 (2009) 8092-8096.

[17] K. Gotoh, T. Kinumoto, E. Fujii, A. Yamamoto, H. Hashimoto, T. Ohkubo, A. Itadani, Y. Kuroda, H. Ishida, Exfoliated graphene sheets decorated with metal/metal oxide nanoparticles: simple preparation from cation exchanged graphite oxide, Carbon 49 (2011) 1118-1125.

[18] W. Wu, R. Hao, F. Liu, X. Su, Y. Hou, Single-crystalline $a-\mathrm{Fe}_{2} \mathrm{O}_{3}$ nanostruc tures: controlled synthesis and high-index plane-enhanced photodegradation by visible light, Journal of Materials Chemistry A 1 (2013) 6888-6894.

[19] Y. Zhang, D. Li, X. Tan, B. Zhang, X. Ruan, H. Liu, C. Pan, L. Liao, T. Zhai, Y. Bando, S. Chen, W. Cai, R.S. Ruoff, High quality graphene sheets from graphene oxide by hot-pressing, Carbon 54 (2013) 143-148.

[20] L. Chen, B. Wei, X. Zhang, C. Li, Bifunctional graphene/ $\left(-y-\mathrm{Fe}_{2} \mathrm{O}_{3}\right.$ hybrid aerogels with double nanocrystalline networks for enzyme immobilization, Small 9 (2013) 2331-2340

[21] Y.J. Mai, D. Zhang, Y.Q. Qiao, C.D. Gu, X.L. Wang, J.P. Tu, MnO/reduced graphene oxide sheet hybrid as an anode for Li-ion batteries with enhanced lithium storage performance, Journal of Power Sources 216 (2012) 201-210.

[22] A.K. Dutta, S.K. Maji, D.N. Srivastava, A. Mondal, P. Biswas, P. Paul, B. Adhikary, Peroxidase-like activity and amperometric sensing of hydrogen peroxide by $\mathrm{Fe}_{2} \mathrm{O}_{3}$ and prussian blue-modified $\mathrm{Fe}_{2} \mathrm{O}_{3}$ nanoparticles, Journal of Molecular Catalysis A: Chemical 360 (2012) 71-77

[23] L. Li, L. He, Y. Tian, H. Wang, A novel hydrogen peroxide sensor based on LaB6 electrode, Electrochimica Acta 63 (2012) 64-68.

[24] J. Hrbac, V. Halouzka, R. Zboril, K. Papadopoulos, T. Triantis, Carbon electrodes modified by nanoscopic iron(III) oxides to assemble chemical sensors for the hydrogen peroxide amperometric detection, Electroanalysis 19 (2007) $1850-1854$

[25] M. Magro, D. Baratella, N. Pianca, A. Toninello, S. Grancara, R. Zboril, F. Vianello, Electrochemical determination of hydrogen peroxide production by isolated mitochondria: a novel nanocomposite carbon-maghemite nanoparticles elec trode, Sensors and Actuators B 176 (2013) 315-322.

\section{Biographies}

Mingyan Wang received her doctor's degree in Nanjing University of Science and Technology in 2011. At present, she works at Huaihai Institute of Technology. She is mainly engaged in the fields of the preparation of nanomaterials and investigating their catalytic and electrocatalytic activities towards some biomolecules with the aim to develop advanced materials in the application of biosensors.

Tao Shen received his bachelor's degree in Huaihai Institute of Technology. He has research interests in the preparation of transition metal oxides nanocomposites.

Meng Wang received his master's degree in East China University of Science and Technology. At present, he works at Australian Institute of Innovative Materials of University of Wollongong. His main interest and research has focused on the preparation and development of nano noble metal materials for the use in metal-air batteries.

Dongen Zhang received his doctor's degree in Chinese Academy of Sciences in 2008. At present, he works at Huaihai Institute of Technology. His research interest include the preparation of nanomaterials and in the application of solar energy cell.

Zhiwei Tong is a professor of Huaihai Institute of Technology. His research interest include the preparation of nanomaterials and in the application of solar energy cell.

Jun Chen is a professor of University of Wollongong. He has research interests in the preparation of nanostructured electromaterials, especially carbon nanotube based 3D architectures, and in fuel cell applications, including cell design and catalytic electrodes. 